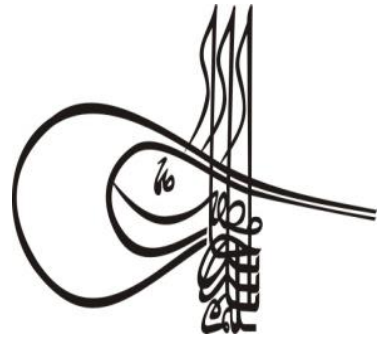

Received/Geliș: 08.04.2019
Tutkish Studies

\section{Social Sciences}

Volume 14 Issue 3,2019, p. 1139-1158

DOI: 10.29228/TurkishStudies.22894

ISSN: 2667-5617

Skopje/MACEDONIA-Ankara/TURKEY

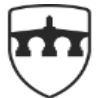

INTERNATIONAL BALKAN UNIVERSITY

EXCELLENCE FOR THE FUTUR IBU.EDU.MK

Research Article / Araştırma Makalesi

A rt i cle Info/Makale Bilgisi

Gor Report Dates/Rapor Tarihleri: Referee 1 (27.05.2019)-Referee 2 (16.04.2019)-Referee 3 (10.05.2019)

This article was checked by iThenticate.

\title{
SAMSAT KAZILARINDA BULUNAN CAM KANDİLLER
}

\author{
Zekiye UYSAL*
}

\section{ÖZ}

Geçmişi M.Ö. 4. binlere kadar inen Samsat; birçok uygarlığın izlerini taşır. Bir süre Komagene Krallığına başkentlik eden kent; Roma ve Bizans egemenliğinin ardından Müslümanlar tarafından fethedilir. 7 . yüzyıldan 11. yüzyıl sonlarına kadar Bizans ve İslam devletleri arasında el değiştiren şehirde, 12. yüzyılda Selçuklu egemenliği başlar. Artuklu, Zengî ve Eyyûbî idarelerinin ardından Dulkadırlı ve Osmanlı devirlerini yaşayan Samsat, günümüzde Atatürk baraj gölünün altında kalmıştır. Burada baraj inşaatı nedeniyle yapılan arkeolojik kurtarma kazılarında çok sayıda cam buluntu ele geçmiștir. Bunlar arasında cam kandiller önemli bir grup oluştururlar. Bu makalede, Adıyaman Müzesi'nde korunmakta olan Samsat cam buluntuları arasından seçilmiş 20 adet cam kandil parçası ele alınmıştır. Geç Roma - Erken Bizans devrinden itibaren tarihlendirilebilen cam kandillerin çoğu Bizans ve Ortaçağ İslam dönemlerinden kalmıslardır. Bunlar kazının I, II ve III. tabakalarında bulunmuşlardır. Bir örneğin dışında kandillerin tümü kırıktır. Serbest üfleme tekniğinde yapılan kandillerde şeffaf renksiz camın yanı sıra kobalt mavisi, yeşilimtırak ve nefti yeşil renkte camlar da kullanılmıştır. Ele geçen kandillerde hiç bezeme görülmez. Bunlar tipolojik açıdan; bardak biçimli, kulplu kâse gövdeli, çubuklu, vazo biçimli, omuzlu ve yumurta biçimli olmak üzere altı gruba ayrılırlar.

Bunlardan bardak tipli parça Roma veya Erken Bizans dönemine; içi boş çubuklu bir kandil parçası ise Erken Bizans dönemine aittir. Boğumlu çubuklu kandiller, kâse tipliler ile ucu bilyeli-çubuklu kandiller hem Bizans hem de Ortaçağ İslam döneminde görülürler. Buna karş11ık vazo tipli ve omuzlu kandil örnekleri İslamî dönemden kalmışlardır. Diğerlerinden farklı olarak yumurta tipli kandiller sadece Samsat kazılarında bulunmuşlardır. Bunlar, bulundukları arkeolojik 
tabaka açısından 12-13. yüzyıllara ve Selçuklu devrine verilebilirler. Kazılarda ele geçen bir grup kulpun cam kandillere ait olduklarını düşünüyoruz.

Anahtar kelimeler: Samsat, Cam, Kandil, Bizans, Ortaçağ İslam sanat1

\title{
GLASS OIL LAMPS FOUND IN SAMSAT EXCAVATIONS
}

\begin{abstract}
Samsat, history of which goes back around 4000 BC, carries the traces of many civilizations. After serving as the capital city of Commagene kingdom for a while, it was conquered by Muslims following the Roman and Byzantine sovereignty. Having changed hands between Byzantine and Islamic states from 7 th to end of 11 th century, the city enters into Seljuk domination in the 12th century. Samsat, having went through Dulkadir and Ottoman periods following the Artuqid, Zengîd and Ayyubid administrations, is now located beneath the Atatürk reservoir. During archaeological salvage excavations performed here due to the dam construction, a multitude of glass findings were obtained. Among these, glass oil lamps form an important group.In this article, 20 pieces of glass lamps selected from the Samsat glass finds preserved in Adiyaman Museum are discussed. Most of the glass oil lamps that can be dated from the Late Roman - Early Byzantine period are from the Byzantine and Medieval periods of Islam. These are excavations I,II and III found in layers.All of the oil lamps, other than one sample, are broken. In these oil lamps, which were produced with free blowing technique; transparent colorless glass, as well cobalt blue, greenish and dark green colored glasses were used. There were no ornaments on the obtained oil lamps. These are typologically divided into six groups; cup-shaped, bowl body with handle, striped, vase-shaped, shouldered and egg-shaped.

Among these, the cup-shaped piece belong to the Rome or Early Byzantine period and an oil lampwith a hollow stem belongs to the Early Byzantine period. Knucled-striped type, bowl-type and ballstriped oil lamps are seen in both Byzantine and Medieval Islam periods. On the other hand, vase-type and shouldered oil lamp samples are from the Islamic period. Unlike the others, egg-type oil lamps were found only in Samsat excavations. It can be dated 12.-13. century in termof archeological context, and Seljuk period. We think that a group of handles found in the excavations belonged to glass oil lamps.
\end{abstract}

\section{STRUCTURED ABSTRACT}

Samsat, whose history dates back to $4000 \mathrm{BC}$, carries the traces of many civilizations. After serving as the capital city of Commagene Kingdom for a while, the town was conquered by Muslims following the Roman and Byzantine sovereignty. In the city, the control of which changed between the Byzantine and Islamic states from the 7th century until the end of the 11th century, the Seljuk sovereignty began in the 
12th century. Samsat, which went through Dulkadir and Ottoman periods following the Artuqid, Zengid and Ayyubid administrations, is now beneath the Atatürk Dam Lake. Here, a large number of glass findings were obtained in archaeological rescue excavations executed by Prof. Dr. Nimet Özgüç due to the dam construction. These glasses were mainly found in the 1st, 2nd and 3rd layers of the mound and the lower city. It is understood from the information in the excavation book that the 1st layer refers to the Seljuk period and afterwards, the 2nd and 3rd layers rather indicate the Early Islamic and Byzantine periods. Accordingly, it is observed in the 2nd and 3rd layers that the control of the city kept changing between the Byzantine and Islamic states in Byzantine, Umayyad and Abbasid periods. Among these, glass oil lamps constitute an important group. Samsat glass oil lamps exhibit a variety that can be considered typologically rich.

In this article, 20 pieces of glass oil lamps selected from Samsat glass findings, which are preserved at Adiyaman Museum, are discussed. Oil lamp pieces were examined in terms of material, technique, form, typology and date. As the stratigraphic details regarding the glass findings are not sufficient in the published excavation reports, books and museum records, style and technical properties were considered for the determination of the oil lamps' belonging and dates. Most of the glass oil lamps, which can be dated back to the Late Roman - Early Byzantine period, remained from the Byzantine and Middle Age Islamic periods. These were found in the 1st, 2nd and 3rd layers of the excavation. All the oil lamps, except for one example, are broken. There were no ornaments on the oil lamps obtained.

These oil lamps were produced with the free blowing technique. The handles seen on the vase typed oil lamps and bowl bodied oil lamps were added after the container was shaped. Fourteenof the pieces we examined (Cat.no.2,7,8,9,10,11,12,13,14,16,17,18,19,20) were made of transparent colorless glass. One example is cobalt blue (Cat.no.3) and another example is dark green (Cat.no. 4). In four pieces (Cat.no.1,5,6,15), transparent greenish color is observed.

These are typologically divided into six groups; cup shaped, bowl bodied with handle, striped, vase shaped, shouldered and egg shaped.

The bell shaped ones among the cup shaped oil lamps are generally referred to the 2nd-4th centuries in the publications. However, it is possible to see examples of this form of oil lamps back till the 7th century. For this reason, the cup shaped oil lamps can be dated back to the 2nd-7th centuries in the widest time frame.

The handled bowl bodied oil lamp type, which is represented by an example among Samsat findings, was applied both during the Byzantine period and the Early Islamic period. Examples of this type encountered in the Byzantine centers in Anatolia date back to the 1112 th centuries. However, bowl bodied oil lamps with handles in the regions of Syria-Palestine and Jordan are identified from the 5th century onward and associated with the Byzantine, Umayyad and Abbasid periods. The period between the 5th and 8th centuries was suggested for this example considering the geographical neighborhood of Samsat with those regions and its history. 
As a subgroup of the striped oil lamps, hollow, gnarled striped and ball tipped types were encountered. Hollow striped oil lamps date back to the Early Byzantine period. We dated our single example from this group to the Early Byzantine period (5-7th centuries) considering the duration of the Byzantine sovereignty in the region. The pieces from the gnarled striped group can be dated back to the 4-8th centuries by remembering the similar examples especially from the region of Palestine. Ball tipped oil lamps were produced in quite a wide time frame from the 5th century until the 14th century. It is understood that such oil lamps were produced and used in both the Byzantine and Islamic geographies in terms of periods. These can date back to 5-12th centuries in the widest time frame considering both the Byzantine and the Islamic sovereignty in the city.

Vase shaped oil lamps constitute the type which was extensively used in the Islamic glass art. The early examples of this type in the Islamic glazing date back to the period between the 8th and 10th centuries. Examples are rarely known from the 7 th century. During the Memluk period, these oil lamps were produced in various heights and their surfaces were adorned with the enameling technique. Our oil lamps are not so ornamental, flamboyant and big as these examples. With their simple design, they resemble the examples uncovered in the Kubad Abad and Beçin excavations. However, they remind us rather of the non-ornamented and small-sized oil lamps in Nishapur, Berlin Staatliche Museum and El-Sabah collection in terms of both their small size and non-ornamented design. We think that our examples are the Islamic works that remained from the 10-12th centuries just like the aforementioned oil lamps, which were reported to originate from the Near East, Syria or Iran. This chronology also suggests that Samsat oil lamps could have remained from the Seljuk period.

We come across an example from the group of shouldered oil lamps in Samsat. The first examples of this rare type were found in the excavations of Kubad Abad and dated to the 13th century. Samsat's shouldered oil lamp piece must be referred to the 13th century as one of the rare examples of this type.

For the egg shaped oil lamp type, we only know the examples from Samsat. This oil lamp type was encountered neither in the Byzantine area nor in other Islamic centers. However, the results that will be obtained in new researches and excavations may change this determination. The present findings show that Samsat is the production area of the egg shaped oil lamps at least for now. On the other hand, the fact that two of them were found in the 1st culture layer accommodating the Seljuks and the afterwards in the mound, in the building which was called "tower" and carried Seljuk characteristics shows that the aforementioned oil lamps remained from the 12-13th centuries.

It is difficult to determine whether the oil lamps were produced in Samsat as no furnaces were discovered during Samsat excavations. But the glass bullions found indicate that there had been production here since the Byzantine period. It can be said that this production also continued in the Islamic period. We do not doubt that the cup shaped oil lamp (Cat.no.1) and hollow striped examples (Cat.no. 3) among the glass oil lamps which were found during Samsat excavations belonged 
to the Byzantine period. However, it is accepted that the bowl typed oil lamps, gnarled striped and ball tipped striped oil lamps were made in both the Byzantine and the Islamic periods. Therefore, it is possible for the bowl typed oil lamps (Cat.no.2), gnarled striped (Cat.no.4,5,6) and ball tipped oil lamp pieces (Cat.no.7,8,9,10,11,12,13,14) to have been produced in both periods. Moreover, the vase typed (Cat.no.15) and shouldered (Cat.16) oil lamp pieces belong to the Islamic period. However, it is not possible for now to state a period and date for the egg-typed lamps (Cat.no.17,18,19,20), which are only known from Samsat excavations. Although there is no doubt that a group of handles belong to the oil lamps, it is impossible to estimate what type of examples they belong to. On the other hand, it does not escape the attention that the color scale in Samsat oil lamps is limited to transparent colorless, cobalt blue, transparent greenish color and dark green, and they are very simple items decoratively.

Keywords: Samsat,Glass, Lamp, Byzantium, Medieval Islamic art

\section{Giriş}

Tarihte Hahhum, Samasota, Semisat, Sümeysat isimleri ile anılan Samsat'ın tarihi geçmişi M.Ö. 4 binlere kadar gider.(Özgüç, 2009, s.64,88) Çeşitli uygarlıkları bünyesinde barındıran tarihi Samsat şehri günümüzde Atatürk Baraj gölünün suları altında bulunmaktadır. Komagene Krallığına başkentlik etmiş olan yerleşim Roma ve Bizans hakimiyetine de girmiştir. M.S. 7 yüzyıldan itibaren İslam fetihlerine sahne olan yerleşimin 11. yüzyıl sonuna kadar İslam ve Bizans arasında el değiştirdiği görülür. 12. yüzyıldan sonra Selçuklu idaresine geçen şehir Artuklu, Zengî, Eyyûbî gibi emirlikler tarafından yönetilir. (İbn Bibi, 1996, s.30) Daha sonra Dulkadırlı beyliği ardından Osmanlı egemenliğini görürüz. (Demirkent,1997, s.232-236; Turan, 1971, s.666) Cumhuriyet döneminde ise baraj gölü yapımı nedeniyle tarihi Samsat sular altında kalmaya başlayınca, 1988 yılında şimdiki yerine taşınmıştır. İslam coğrafyacıları ve tarihçileri tarafindan bu şehir Ortaçağ'da sağlam bir kale ve Sümeysat olarak adlandırılır. (Goell, 1974, s.92-93) Tarih boyu önemini koruyan Samsat şehri 19. yüzyılın ortalarından itibaren seyyahların ve araştırmacıların dikkatini çekmiştir. Bunlar arasında William Francis Ainsworth ve Helmuth von Moltke gibi seyyahlar; K. Humann, Theresa Goell ve Ümit Serdaroğlu ve Ülkü İzmirligil gibi araştırmacıları sayabiliriz. (Özgüç, 2009, s.1-2; Serdaroğlu, 1977, s. 18-20; İzmirligil, 1987, s.281-289).

Kale ve aşağı şehirden oluşan tarihî Samsat'ta ilk arkeolojik kazılar Theresa Goell tarafindan 1964 ve 1967 yıllarında yapılmıştır. (Goell, 1974, s.83-109) Goell'in kazılarında özellikle 12-13. yüzyıldan Selçuklu ve Eyyubî dönemlerine ait mineli ve yazılı cam kap parçaları dikkati çekmiştir. Bu buluntular daha sonraları Scott Redford tarafindan yayınlanmıştır. (Redford, 1994, s.81-91) Samsat'ta asıl büyük kazı çalışmaları; Atatürk Barajının yapımı nedeniyle Prof. Dr. Nimet Özgüç başkanlığında 1978-1989 yılları arasında gerçekleştirilen kurtarma kazılarıdır. (Özgüç, 2009, önsöz; Bulut, 2000, s.8) Samsat Höyüğü ve aşağı şehirde Nimat Özgüç'ün yaptı̆̆ kazılarda; diğer dönemlerle birlikte Ortaçağ tabakalarında da çok çeşitli malzeme grubundan buluntular ele geçmiştir. Bunlar arasında önemli bir grubu camlar oluşturmasına rağmen henüz Samsat camları ayrıntılı bir biçimde tanıtılmamıştır. $\mathrm{Bu}$ nedenle Kültür ve Turizm Bakanlığı Adıyaman Müze Müdürlüğü’nden aldığımız izin ile araştırmamıza başladık. ${ }^{1}$ Söz konusu camlar esas olarak höyük ve aşağı şehrin I., II. ve III. kültür

\footnotetext{
${ }^{1} \mathrm{Bu}$ araştırma için gerekli izinleri veren T.C. Kültür ve Turizm Bakanlığı Adıyaman Müze Müdürlüğüne, yardım ve destekleri için tüm müze personeline teşekkür ediyorum. Ayrıca Çanakkale Onsekiz Mart Üniversitesi Bilimsel Araştırma Projeleri Koordinasyon Birimine SBA 2017/1308 nolu projemizi destekledikleri için teşekkür ediyorum. Ayrıca buluntuların çizimleri için Dr.Öğr.Üyesi Oğuz Koçyiğit'e ve bu çalışmanın çeşitli aşamalarındaki katkıları için Prof.Dr. A.Osman Uysal'a teşekkür ediyorum.
} 
tabakalarında ele geçmişlerdir. Kazı kitabındaki bilgilerden I. tabakanın Selçuklu ve sonrasını ilgilendirdiği; II. ve III. tabakanın ise daha ziyade Erken İslam ve Bizans dönemlerini içerdiği anlaşılmaktadır. Buna göre II. ve III. tabakalarda Bizans, Emevi ve Abbasi dönemleriyle, şehrin Bizans ve İslam devletleri arasında el değiştirip durduğu devreler izlenmektedir. (Özgüç, 2009, 20-21) 2017 yılında Adıyaman müzesinde gerçekleştirdiğimiz çalışmalarımız sırasında, Özgüç'ün cam buluntuları arasında çeşitli dönemlere ait kandil parçalarını da inceledik.

$\mathrm{Bu}$ örnekler üzerinde durmaya başlamadan önce, kandile dair bazı genel bilgileri paylaşmak yararlı olacaktır.

Aydınlatma araçları arasında yer alan kandil Arapça bir kelime olup aslı "kındil"dir. (Develioğlu,2002, s.487) Bu anlamda Latince'de candela kelimesi kullanılır. Araştırmacılar kandil kelimesinin Latince candeladan geldiğini ileri sürmüşlerdir.(Kalfazade ve Ertuğrul 1989, s.23) İçerisine zeytinyağı ve fitil konarak yakılan ışık veren objeler olarak tanımlanırlar. Antik Mısırlılar, Fenikeliler, elde taşınan kandiller kullanmışlardır. Daha sonra kandil kullanımı Antik Yunan kentlerinden Romalılara geçmiştir. (Arseven,1965, s.936,937) Anadolu'da Bizans ve Selçuklu dönemlerinde daha çok tek kulplu yağ hazneli ve sivri emzik kısmından oluşan seramik kandillere rastlanır. Seramik kandillerin yanı sıra camdan yapılan kandillerin de azımsanmayacak şekilde kullanıldığını çeşitli kazı merkezlerinden gelen buluntular göstermektedir. Kubad Abad (Uysal,2013, s.108-117) Demre (Olcay Uçkan ve Çömezoğlu Uzbek, 2018. s.516-524), Kadıkalesi (Çakmakçı, 2008,s.95-135), Amorium (Gill,2002,s.35-37) Yumuktepe (Köroğlu,1999, s.241-252) gibi merkezler bu açıdan önemlidirler.

Cam kandillerin ilk örneklerine Geç Roma - Erken Bizans döneminde rastlanıldığı belirtilir. (Philippe, 1970, s.78) Bu dönemde çubuklu, kâse biçimli, kadeh biçimli, zarf içi kandil kullanıldığ1 belirtilmektedir.(Olcay, 1997, s.11-114; Olcay, 2001, s.77-87) Ortaçağ İslam camcılığında ise en yaygın cam kandil grubu vazo tipli olanlardır. Ayrıca İslam döneminde kadeh biçimli kandillere (Uysal, 2013, s.108) ve karnından kulplu yumurta biçimli kandillere de rastlanır. (Öney, 1982, s.79)

Müzede yaptığımız çalışmalar sırasında, Samsat'ın Geç Roma - Erken Bizans ve İslami dönem tabakalarında ele geçmiş çeşitli kandil parçaları tasnif edilerek çizimleri yapılmış ve fotoğrafları çekilmiştir. Makalede yöntem olarak, bu parçalardan tipolojik açıdan nitelik taşıyanlar seçilerek katalog oluşturulmuştur.Bu doğrultuda şekillenen kataloğumuz 20 örnekten meydana gelmiştir.

Kataloğumuzda yer alan kandiller serbest üfleme tekniği ile meydana getirilmişlerdir. Vazo tipli kandil ve kâse gövdeli kandil tipinde görülen kulplar ise kap biçimlendirildikten sonra eklenmişlerdir. Bu uygulamada genellikle kulp yapmak için bir parça cam lifi alınır ve gövdeye yapıştırılır sonra alet yardımıyla kulp biçimi verilir; son olarak ta bazen gövde üzerine bazen de ağız kenarına yapıştırılır. (Uysal, 2013, s.109)

İncelediğimizparçalardan Kat.no.2,7,8,9,10,11,12,13,14,16,17,18,19,20 şeffaf renksiz camdan yapılmıştır. Kat.no.3 kobalt mavisi renktedir. Kat.no. 4 de nefti yeşil, kat.no.1,5,6,15 de ise şeffaf yeşilimtrak renk kullanılmıştır.

Samsat'ta Nimet Özgüç kazılarında bulunmuş olup tarafımızdan incelenen cam kandiller üzerinde herhangi bir süslemeye rastlanılmamıştır. Bu durum kandillerin tümünün bezemesiz olarak üretildikleri kanısını uyandırmaktadır.

\section{Tipoloji:}

Samsat kazılarında ele geçen cam kandiller formlarına göre tipolojik açidan sınıflandırıldığında; bardak biçimli, kulplu kâse gövdeli, çubuklu (İçi boş, boğumlu, düz çubuklu ucu bilye şeklinde), vazo biçimli, omuzlu ve yumurta biçimli olmak üzere altı gruba ayrılmaktadırlar. 


\subsection{Bardak Biçimliler:}

$\mathrm{Bu}$ tipteki kandiller, ya asılarak ya da zarf içine konularak kullanılıyordu. Bu grubun, yayınlanmış kazı buluntularında gövdesi kâse biçimli veya çan biçimli olarak düzenlenmiş örnekleri görülmektedir.(Oral, 2008, s.108-117) Bizim örneğimizin gövdesi çan biçimlidir. (Kat.no.1) (Şekil 1, Resim 1) Kaide kısmı kırık olduğu için nasıl sonlandığını bilemiyoruz. Çünkü bu tarz örneklerin kaideleri kare şekilli, yuvarlak şekilli gibi farklı biçimlerde yapılabilmektedir. Gövdesi çan biçimli kandil örneklerinin en erken tarihlisi 2. ve 4 yüzyıla verilir. (Clairmont, 1963,s.755) Daha sonra bu kandil örneklerini 7. yüzyıla kadar görmek mümkündür. Sardes’te bulunan ve Geç Roma Erken Bizans dönemine verilen kandil, örneğimize de benzemektedir. (Saldern, 1980, s.52) Bunlara dayanılarak bu kandil de 2-7. yüzyıllar arasına tarihlenebilir.

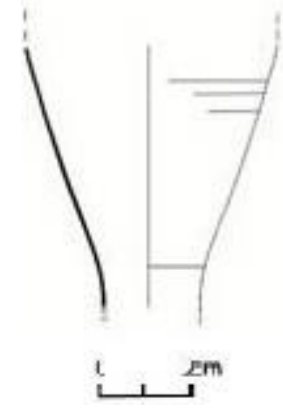

Şekil 1.Bardak tipli

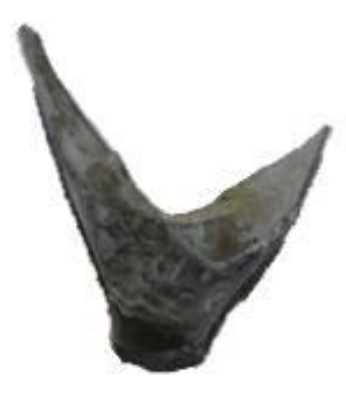

Resim 1. Bardak tipli

\subsection{Kulplu Kâse Gövdeliler:}

Yapılan araştırmalara göre bu tip kandillerin kâse şeklinde gövdeleri vardır. Kulplar bazı örneklerde gövde üzerinde yer alırken; bazılarında ise kulpun üst ucu ağız kenarına bitiştirilmiştir. Bizans dönemi kazılarının çoğunda bu tipte kandillerle karşılaşılımıştır. (Olcay, 1997, s.227-238; Çömezoğlu, 2007, s.115; Olçay Uçkan ve Bulgurlu ve Çömezoğlu, 2007, s.44) Bazı müzelerde bu grup örnekler gibi kulplu olmakla birlikte form bakımından farklılık gösteren kandillerle de karşılaşı1maktadır. (Özgümüş,1993-1994, s.40; Temur, 2018, s.227-267) Aynı biçimde kandile Filistin'de rastlanır. (Crowfoot ve Harden, 1931, s.205) Bu tip kandiller 5. yüzyıldan itibaren bilinmektedir. (Burdajewicz, 2017, s.678) Bu tarz kandillerin bazılarında gövde derinliği fazla değilken bazılarında derin tutulmuştur. (Çakmakçı, 2008, s.71-72) Anadolu'da kulplu kandil örnekleriyle Amorium, Anemurium, Kadıkalesi, Demre gibi merkezlerdeki kazılarda karşılaşılmıştır. (Gill, 2006, s.169, fig.2/1,3) Kadıkalesi'ndeki kulplu kandiller M.S. 11. ve 12. yüzyıla verilirler. (Çakmakç1, 2008, s.317) Demre'de ele geçenler ise 11-12 yüzyıllara tarihlenmişlerdir. Saraçhane kazılarında da benzer kandiller bulunmuştur. (Olcay ve Çömezoğlu, 2018, s.523) Bu tip kandiller Suriye, Filistin, Ürdün ve Misır bölgelerinde de görülmektedir. Ürdün'deki Beit Ras kazılarında bu gruptan kandil parçaları ile karşılaşılmıştır. Bu tip aydınlatma araçlarının Suriye bölgesinde 5. yüzyılın ilk yarısından itibaren ortaya çıktığı ve erken İslam döneminde de devam ettiği belirtilmiştir. Ürdün Filistin bölgesinde Bizans - Emevi dönemlerinden ve erken Abbasi devrinden bu tipin görüldüğü merkezler Khirbat al Karak, Bet Shean, Tiberias, Horvat Karkur, Pella, Jerash, ve Petra'dır. (Hadad, 1998, s.64; Burdajewicz, 2006,s. 130-131) Bunlardan Jerash buluntuları 4-6. yüzyıllara verilmişlerdir. (Gorin-Rosen -Winter, 2010, s.172) Samsat cam buluntuları arasında bu tipe giren tek örnek belirlenebilmiştir. (Kat.no.2) Bu kandillin de gövdesi kâse şeklinde derin tutulmuştur. (Şekil 2, Resim 2) Fakat dip kısmı ele geçmediği için nasıl sonlandığı anlaşılamamaktadır. Şeffaf renksiz camdan 
yapılmış olup, ağız kenarına bitişik olan kulp gövdeyle aynı renktedir. Bu özellikleri ile diğer merkezlerdeki kandillerle benzerlik taşımaktadır ve bölgesel yakınlık dolayısıyla bu kandilin Suriye, Filistin ve Ürdün bölgelerindekilerle kronolojik ortaklığa sahip olduğu düşünülebilir. Bu bakımdan, Samsat tarihinin Bizans ve Erken İslam devirleri ile coğrafî konumu da dikkate alındığında söz konusu kandil örneği 5-8. yüzyıl arasına tarihlenebilir.

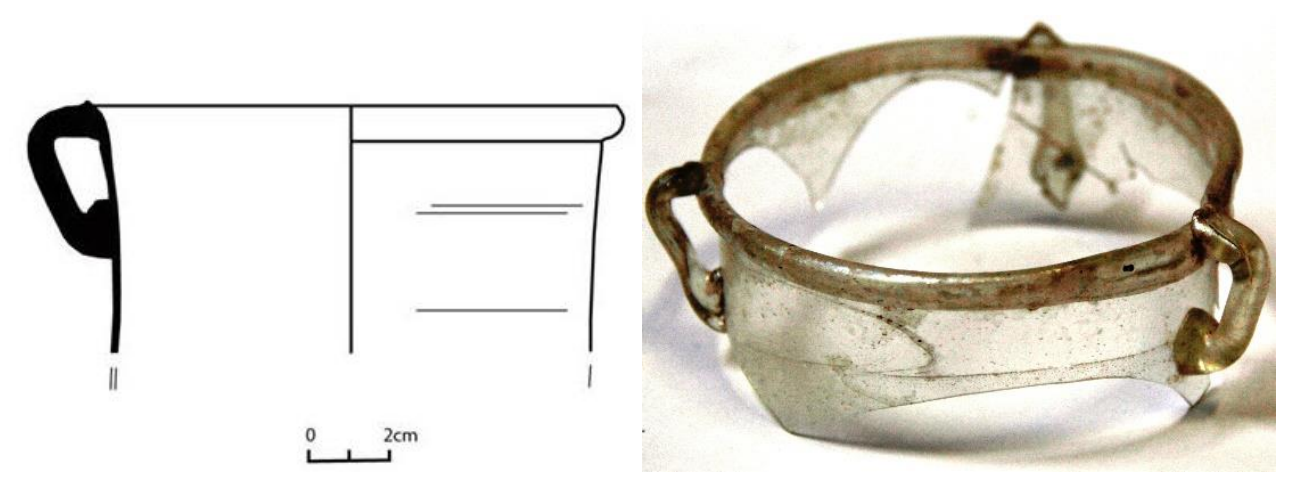

Şekil 2. Kulplu kâse tipli

Resim 2. Kulplu kâse tipli

\section{3. Çubuklu Kandiller:}

Genellikle metal Polikandilonların içerisine yerleştirilerek kullanılırlar. Çubuklu kandiller tipolojik bakımdan zengin bir çeşitlilik ortaya koyarlar. Mevcut bilgilerimize göre bu tip kandiller Bizans döneminde görülmektedir. Araştırmacılar bu tür kandilleri yaklaşık olarak birbirine benzer biçimde sınıflandırmışlardır. (Acara ve Olcay, 1998,s.252; Oral, 2008, s.68-69; Çakmaklı, 2012, s.125) $\mathrm{Bu}$ tip kandillerin sınıflaması çubuğun durumuna göre yapılmıştır. Çoğu yayında ortak olan sınıflama içi boş, birden fazla boğumlu, ucu bilye şeklinde ve masif olmak üzere dört grup şeklinde karşımıza çıkar. (Çakmakçı, 2008, s.307) Samsat kazılarında içi boş, birden fazla boğumlu, ucu bilye şeklinde olan çubuklu kandil formları ele geçmiştir.

\subsection{1.İçi Boş Çubuklular:}

$\mathrm{Bu}$ tip kandillerde çubuk kısmının içinin sivri bir aletle açılarak biçimlendirildiği bilinmektedir. (Acara ve Olcay, 1998, s.252) Bu grup kandillerden Samsat kazılarında bir parça belirlenebilmiştir. (Kat.no.3) Bu parça kobalt mavisi renktedir. (Şekil 3, Resim 3)İçi boş çubuklu kandillerin Anadolu ve diğer bölgelerde ele geçen örnekleri Erken Bizans dönemine tarihlenmektedir. (Olcay, 2017, s.199) İçi boş çubuk biçimlerinin yağ miktarını artırmak için tasarlandığı ileri sürülmüştür. (Olcay, 2017, s.199)Bu tipin Anadolu'da ele geçen örneklerinden Amorium'dakiler 4-5. yüzyıllara (Gill s.35 fig.1/2), Demre'dekiler 6. yüzyıl sonu - 7 yüzyıla tarihlenirler. (Olcay Uçkan ve Çömezoğlu Uzbek, 2018. s.516.) Kadıkalesi buluntuları ise 5-7. yüzyıla verilir. (Çakmakçı, 2008, s.96) Yumuktepe buluntuları da diğerleri gibi erken Bizans dönemine verilmişlerdir. (Köroğlu, 2009, s.239) Bu tipin erken örnekleriyle 5. yüzyılda Mısır'da da karşılaşılması kullanım alanının yaygınlığı açısından önemlidir. (Kucharczyk, 2008, s.61) Bölgedeki Bizans egemenlik süresi ve yukarıda sıralanan merkezlerdeki benzer örnekler dikkate alındığında Samsat'ta ele geçen içi boş çubuklu kandil de erken Bizans dönemine ( 5 -7 yy) verilebilir. 


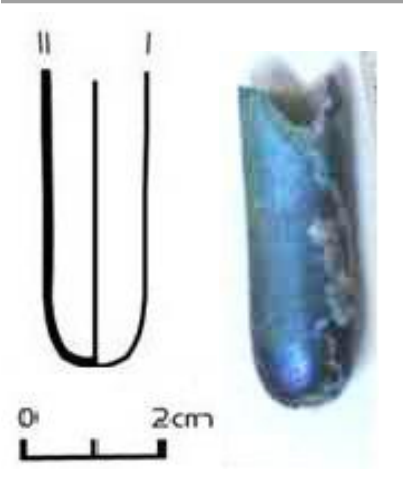

Şekil 3. İçi boş çubuklu Resim 3. İçi boş çubuklu

\subsubsection{Boğumlu Çubuklular:}

Çubuklu kandillerin bu grubu çok yaygın olmayıp, bilinen örneklerinin erken Bizans dönemine tarihlendikleri ileri sürülmüştür. (Olcay Uçkan ve Çömezoğlu Uzbek, 2018, s.516) Fakat bu grubun özellikle Filistin bölgesinde ele geçen varyasyonları için 4. yüzyıldan 8. yüzyılın ilk yarısına kadar tarihler önerilmiştir. (Hadad, 1998, s.69) Bu kronoloji söz konusu bölgede Erken Bizans ve Emevî dönemlerine uygun düşer. Bu tip parçalar boğumlu -çubuklu kadehlerle benzerlik gösterirler. Bunları birbirinden ayıran temel özellik bu tür kadehlerin boğumlu çubuklarının altında bir de kaidenin bulunmasıdır. Fakat bunların alt ve üst kısımları ele geçmediği zaman bunların kadeh mi yoksa kandil mi olduğu ayırt edilememektedir. Samsat kazılarında bu gruptan üç adet ele geçmiştir. (Kat. no.4,5,6) Bu parçalar biçimleri itibariyle boğumlu çubuklu kandile ait oldukları konusunda kuşkuya yer bırakmazlar. (Şekil 4,5,6; Resim 4,5,6) Masif karakterde çubuğa sahip bu tip kandillerle Filistin'deki Bet Shean, Kursi, Mount Nebo, Jerash ve Geresa dışında Anadolu'da Demre kazılarında da karşılaşılmıştır. Bunlardan Filistin bölgesinde Bet Shean, Kursi, Mount Nebo ve Jerash'ta ele geçenler Crowfoot ve Harden tarafindan 4-5. yüzyıllara; Baur tarafindan 5-6 yüzyıllara, Meyer tarafından 7. yüzyıla ve Emevi devrine; Gawlikowski, Musa ve Kehrberg tarafından 8. yüzyılın ilk yarısına tarihlenirler. (Hadad, 1998, s.69), Demre buluntuları ise 5-7 yüzyıllara verilmişlerdir. (Olcay Uçkan ve Çömezoğlu Uzbek, 2018, s.516-517) Bu örneklere ve Samsat'ta Bizans ve İslam egemenliğinin kronolojisine dayanarak, incelediğimiz boğumlu çubuklu parçaları en geniş sınırıyla 4 8. yüzyıllar arasına tarihlenebilirler. Buna göre Samsat'ın boğumlu çubuklu kandillerinin Bizans işi olabilecekleri gibi Emevî dönemlerinde de üretilmiş olabilecekleri kabul edilebilir. 


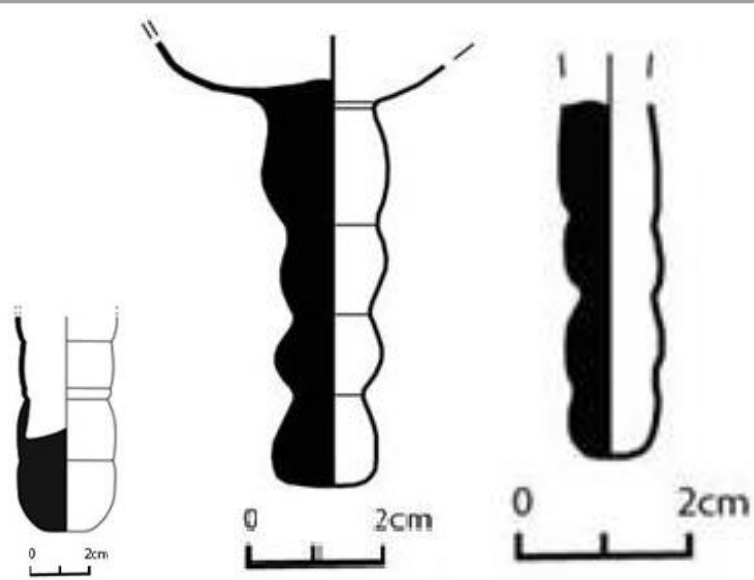

Şekil 4.Boğumlu çubuklu Şekil 5.Boğumlu çubuklu

Şekil 6.Boğumlu çubuklu

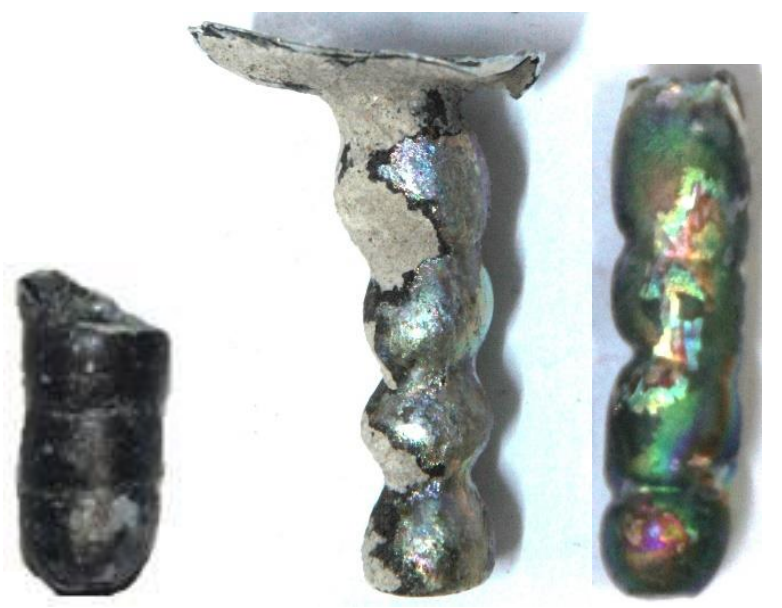

Resim 4. Boğumlu çubuklu Resim 5. Boğumlu çubuklu Resim 6. Boğumlu çubuklu

\subsubsection{Ucu Bilye Biçiminde Düz Çubuklular:}

$\mathrm{Bu}$ grup kandillerin düz çubuk kısmı masiftir. Çubuğun gövdeye geçiş kısmı eğimlidir. Çubuğun dip kısmı bilye şeklinde biçimlendirilmiştir. Anadolu'nun yanı sıra Irak, Suriye, Filistin, İran, Sudan ve Mısır'da bu tipin örnekleriyle sıklıkla karşılaşılır. Bunlar 5. yüzyıldan 14. yüzyıla kadar geniş bir zaman aralığında kullanılmışlardır. (Hadad, 1998, s.69; Çakmakçı, 2008, s.311) Bunlardan Samarra örnekleri 8. yüzyıla tarihlenir. (Olcay Uçkan ve Çömezoğlu Uzbek, 2018, s. 518) Bu tip örneklere Fustat'ta da rastlanmıştır. Bunlar 9. ve 10 yüzyıla tarihlenmişlerdir. ( Pinder-Wilson ve Scanlon, 1973, s.22) Demre örnekleri 10. yüzyıla tarihlendirilirler. ( Olcay Uçkan ve Çömezoğlu Uzbek, 2018, s.518) Corint’te bulunan örnekler 11- 12. yüzyıla verilmişlerdir. (Davidson, 1952, s.121.) Bu grubun kısa çubuklu bir örneğine Filistin'de rastlanmıştır. (Lamm,1929, Tafel30/20)Suriye ya da Misırda üretildiği düşünülen bu kandil parçası 7-9. yüzyıla tarihlenmiştir. ( Davidson, 1952, s.121). Bu tip kandillerden Hama'da da bulunmuştur. Hama'da ele geçen kandil parçasının 
muhtemelen 11-12. yüzyıldan kaldığı vurgulanmıştır. ( Riis ve Poulsen, 1957, s.39) Bu tipin Sudan'da ele geçen örnekleri 10-14. yüzy1llara; İran Siraf ve İran körfezinde bulunanlar ise 13-14. yüzy1llara verilmişlerdir. (Hadad, 1998, s.69) Bu örnekler, ucu bilyeli cam kandillerin Irak, Suriye, Filistin, Mısır, Sudan ve İran gibi İslam ülkelerinde; ilk İslam devrinden itibaren Emevi, Abbasi, Selçuklu ve İlhanlı devirlerinde üretildiklerini ortaya koymaktadır. Samsat kazılarında bulunan bu grup kandillerin çubuk kısımları veya çubuk kısımlarıyla birlikte gövde başlangıçları ele geçmiştir. (Kat.no. $7,8,9,10,11,12,13,14)$ Bunlarda en alttaki bilye kısmından gövdeye doğru düz yüzeyli çubuk hafifçe genişlemektedir. (Şekil 7,8,9,10,11,12,13,14; Resim 7,8,9,10,11,12,13,14) Bu gruptaki kandil parçaları; kentteki hem Bizans hem de İslam egemenliğiyle birlikte, Suriye örneklerinin kronolojisi dikkate alınarak en geniş zaman aralığıyla 5-12. yüzyıllara tarihlenebilirler.

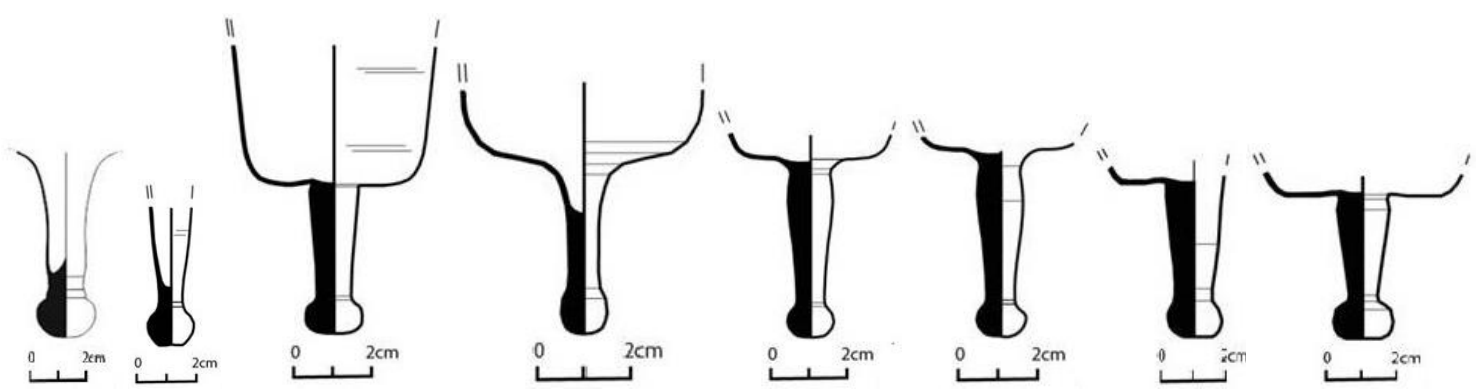

Şekil 7,8,9,10,11,12,13,14. Ucu bilye biçimli çubuklu kandil parçaları

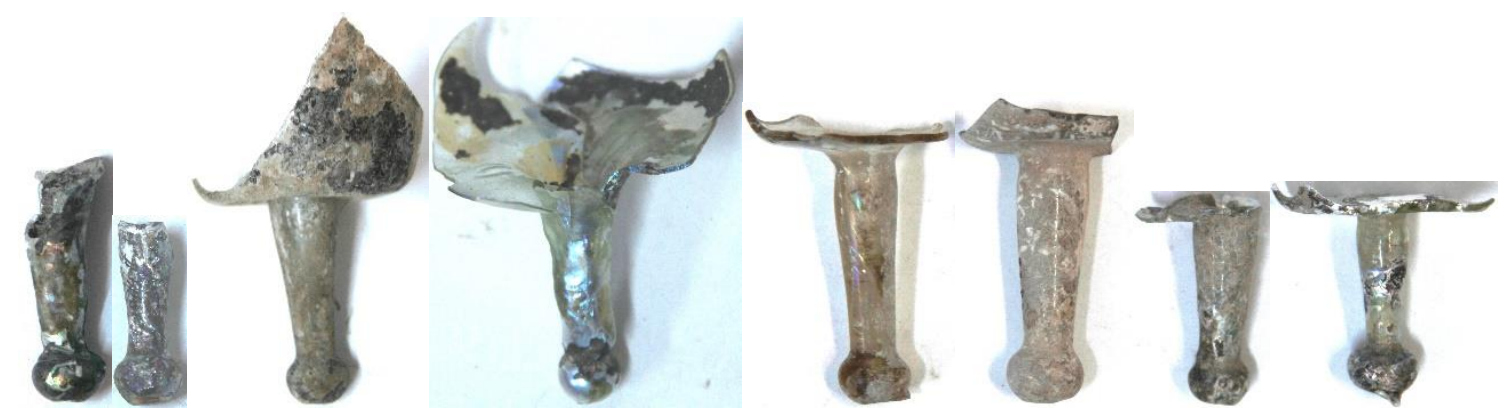

Resim 7,8,9,10,11,12,13,14. Ucu bilye biçimli çubuklu kandil parçaları

\subsection{Vazo Biçimli Kandiller:}

İslam cam sanatında yaygın olarak kullanılan kandil tipidir. Bu tipteki kandiller kaideli, küresel gövdeli ve yukarıya doğru genişleyen ters konik boyunlu ve kulpludurlar. Gövdenin üzerinde bazen üç bazen altı kulp bulunur. Bu kulplardan geçen zincirlerle asılarak kullanılırlar. İslam camcilığında bu tipin erken örnekleri 8-10. yüzyıllar arasına tarihlenmektedir. Nadiren 7. yüzyıldan örnekler bilinmektedir. (Lamm,1930, s. 93) Vazo tipli kandillerin boyutları çeşitli farklılıklar gösterir. Mesela $7.7 \mathrm{~cm}$ yüksekliğinde küçük boyutlusundan, $42 \mathrm{~cm}$ yüksekliğinde olanlara kadar çeşitleri mevcuttur. Gövde biçimleri bazen basık küresel gövdeli olabilmekte, bazıları ters koniye benzeyen gövdeli olabilmektedir (Carboni, 2001, s.166-167) Vazo tipli kandillerin mineleme tekniği ile süslenmiş örnekleri 13. yüzyıldan itibaren Eyyûbî ve Memlük dönemlerinde Halep ve Şam gibi merkezlerde yapılmıştır. (Wiet, 1929, s.5-92) Anadolu'da vazo tipli kandille ilk kez Yumuktepe kazısında karşılaşılmıştır. 13. yüzyıla tarihlenen bu eserin Suriye merkezlerinden ithal edildiği düşünülür. (Köroğlu, 1999, s.245-249) KubadAbad kazılarında da vazo tipli kandil parçaları bulunmuştur. (Uysal, 2013, s.116-117) Batı Anadolu'da Menteşe beyliğinin merkezlerinden Beçin 
kazılarında aynı tipte bir kandil (14. yüzy1l) ile karşıllaşılması, bunların Beylikler devrinde de aydınlatma araçları arasında yer aldığını göstermektedir. (Gök, 2004, s.33-41)

Genellikle İslami döneme özgü olduğu kabul edilen bu kandil tipinin erken Bizans döneminde bilinen ve kullanılan bir form olduğu da ileri sürülmüştür. (Çakmakçı, 2017, s.163-180)

Samsat buluntuları arasında yer alan vazo tipli kandil; küçük boyutlu, küresel gövdeli, ters konik boyunlu ve kulpludur. (Kat.no.15) Şeffaf yeşilimtrak renkte olan kandilin yarısı kırıktır. Üzerinde herhangi bir bezeme görülmemektedir. (Şekil 15; Resim 15) Kandil, 9 cm.lik yüksekliği ve sade görünümüyle; ünlü Memlûk kandillerinin yanında çok küçük ve sönük kalır. Nişapur'da bulunan ve $12,2 \mathrm{~cm}$. yüksekliğiyle vazo tiplilerin küçük boyutlu grubuna giren bezemesiz kandilin 10-11. yüzyıldan kaldığı kaydedilmiştir. (Kröger, 1995, s.182) Benzer biçimde küçük boyutlu bir kandil de Berlin Staatliche Museum'da yer almaktadır. Yüksekliği 8. cm olan bu kandilin de 10-12. yüzylllara tarihlenmiş olması ilginçtir.(Yonar, 2003, s.91-93) El Sabah koleksiyonunda yer alan ve $7.7 \mathrm{~cm}$. lik yüksekliği ile örneğimize benzeyen bir cam kandil ise 11. yüzylla tarihlenmiştir. Söz konusu kandilin Suriye ya da İran bölgesinden geldiği anlaşılmaktadır. (Carboni, 2001, s.167) El Sabah koleksiyonundaki bu kandil, bezemesiz oluşuyla örneğimize benzemekle birlikte; kaide ve kulp biçimi açılarından farklıdır. Bununla birlikte; bölgesel yakınlık ve boyut bakımından benzerlik anlamlıdır. $\mathrm{Bu}$ bakımdan Samsat örneğinin tarihlendirilmesinde dikkate alınabileceğini düşünüyoruz. Söz konusu mukayese örneklerinden hareketle Samsat kandili, İslami döneme ve 10-12. yüzy1llara tarihlenebilir.

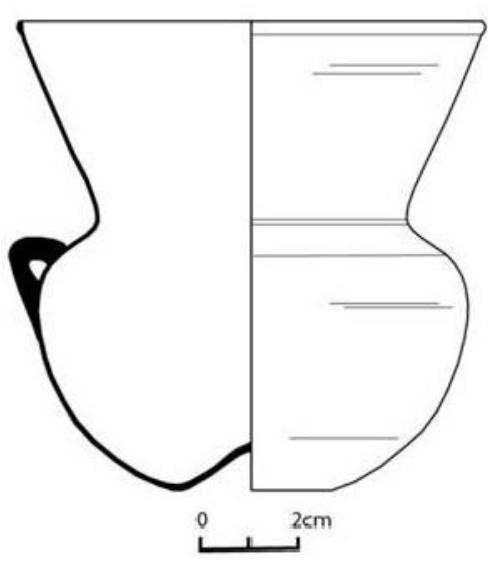

Şekil 15. Vazo biçimli kandil

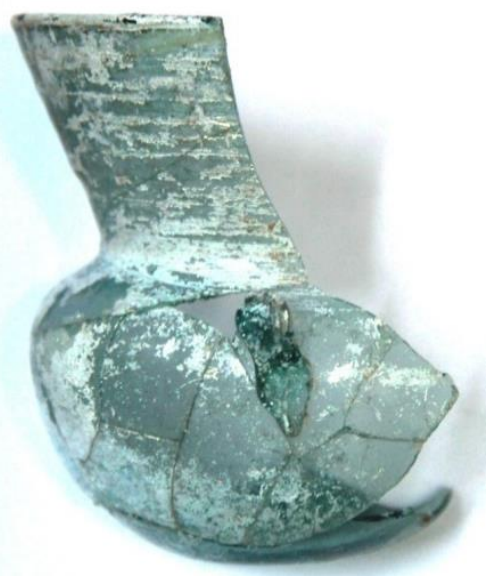

Resim 15. Vazo biçimli kandil

\subsection{Omuzlu Kandiller:}

Omuzlu kandiller silindirik boyunlu, üst kısmı omuz gibi biçimlendirilmiş alt tarafı dar ve küresel gövdeli kulpsuz ve küçük boyutludurlar. Bu tip kandil ilk kez Kubadabad kazılarında tespit edilmiştir. (Uysal, 2007, s.725-734) Kubad Abad Sarayı kazılarında bu tipteki kandillerden altı adet ele geçmiştir. Bunlardan ikisi restore edilebilmişlerdir. (Uysal, 2013, s.109-110) Samsat höyüğünde ise bu tipte bir adet kandil tespit edilmiştir. Şeffaf renksiz camdan yapılan kandilin omuz, gövde ve kaidesinin bir kısmı ele geçmiştir. Vurma dipli kaide çapı $4 \mathrm{~cm}$, mevcut gövde yüksekliği ise $12 \mathrm{~cm}$ civarı olan bu kandilin kulpları olmadığına göre asılarak kullanılmadığı kesindir. Bu tip kandiller, diplerinin gövdeye göre daha dar olmasından dolayı sehpa üzenine de konularak kullanılamazlar. $\mathrm{Bu}$ nedenlerle omuzlu kandillerin tunç veya başka metalden kandil zarflarına konularak kullanılmış olabileceklerini düşünüyoruz. (Uysal, 2007, s.726) Mevcut bilgilerimize göre; omuzlu kandillerle, Bizans dönemi merkezlerinde ve Ortaçağ İslam dünyasının diğer merkezlerinde henüz 
karşılaşılmamıştır. Bu kandillerin tanımlanabilen ilk örnekleri -yukarıda belirtildiği gibi - Kubad Abad'da bulunmuş ve stratigrafik veriler doğrultusunda 13. yüzyıla tarihlenmişlerdir. Samsat, Kubad Abad'dan sonra bu tiple karşılaşılan ikinci merkezdir. Samsat'taki örnek de, Kubad Abad'da olduğu gibi sağlam ele geçmemiştir. (Kat.no.16) Gövde hakkında fikir verebilen bir parçadan ibarettir. Sade biçimli, vurma dipli ve yukarıya doğru genişleyen basık gövdelidir.(Şekil 16; Resim 16) Gövdenin sonunda içeri doğru kıvrılarak inen omuz kısmının bağlandığı boyun ve yukarısı ele geçmemiştir. $\mathrm{Bu}$ nedenle kandilin nasıl tamamlandığını kestirmek güçtür. Fakat bunun da Kubad Abad örnekleri gibi biçimlendiği tahmin edilebilir. Henüz bu tip kandillerin üretim yeri konusunda kesin bir bilgiye sahip değiliz. Samsat'ta cam üretimine dair arkeolojik bulgulara rastlanılmış olmasına rağmen, üretim çeşitleri kesin olarak belirlenememiştir. $\mathrm{Bu}$ nedenle, şimdilik nadiren karşılaşılan bir tipin sayılı örneklerinden birisi olan omuzlu kandilin Samsat üretimi olup olmadığını bilemiyoruz. Samsat, her ne kadar coğrafi bakımdan Suriye bölgesine dönük olsa da; idari bakımdan bir süre Selçuklu yönetiminde kalmış bir yerleşimdir. Dolayısıyla, burada ele geçen omuzlu kandil; yerel üretim ürünü değilse, ya Suriye bölgesinden ya da Anadolu içlerinden gelmiş olabilir. Geliş yeri neresi olursa olsun, bu örneğin yegâne benzerleri Kubad Abad'da ele geçtiklerinden, tarihlendirme için söz konusu örnekler dikkate alınmak zorundadır. Bu nedenle Samsat'ın omuzlu kandili, Kubad Abad örneklerinden hareketle 13. yüzylla tarihlendirilebilir.

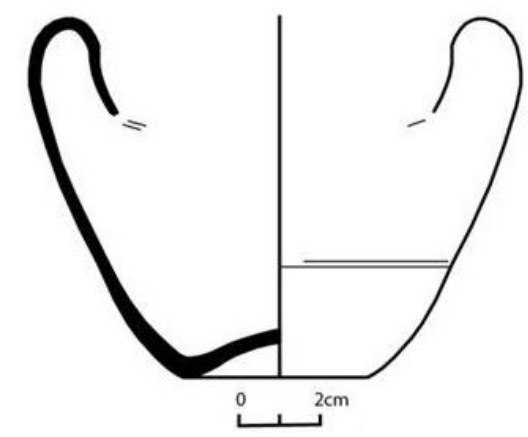

Şekil 16. Omuzlu kandil parçası

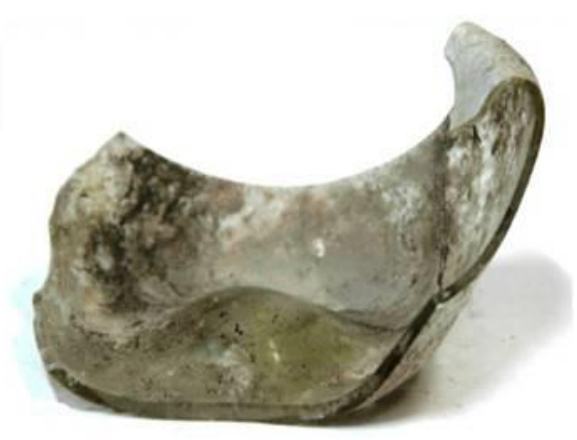

Resim 16. Omuzlu kandil parçası

\subsection{Yumurta Biçimli Kandiller:}

$\mathrm{Bu}$ tipteki kandiller yumurta biçiminde gövdeli ve boncuk diplidirler. Boncuk dibin içi doludur. Gövdenin üst kısmındaki ağız içe dönük biçimde olup kısa bir boyunla gövdeye bağlanır. Gövdenin ortasında kalın profilli düzgün olmayan dört köşeli bir delik yer alır. Diğer kandil tiplerine hiç benzemeyen bu kandilin kullanılış tarzı alışılmışın dışındadır. Büyük bir ihtimalle gövdenin ortasındaki bir deliğe çubuk takılarak boncuk dip aşağı, ağız kısmı yukarı gelecek biçimde kullanıliyorlard1.

Mevcut literatüre göre Bizans merkezlerinde hiç karşılaşılmayan bu tip kandiller Samsat'in dışındaki İslam merkezlerinde de görülmemektedir. Fakat yeni yapılacak araştırma ve kazılarda bu tespiti değiştirebilecek sonuçların çıkması olasıdır. Samsat kazılarında Özgüç’ün yayınında gösterdiği örnekler, höyük kesiminde "kule" denilen ortaçağ yapısında ele geçmiştir. (Özgüç, 2009, s.20) Bu yapı, plan ve mimari açıdan Selçuklu devri özellikleri yansıtmaktadır. Elimizdeki verilere göre bu tipte literatüre geçmiş durumda çok az örnek vardır. Bu tip ile ilk kez karşılaşı̆̆ı̆ımız Hüseyin Kocabaş Koleksiyonunda üç örnek tanıtılmıştır. Bu koleksiyonun yayınlanmış kataloğunda söz konusu örneklerin emzik olarak tanımlandıkları dikkati çeker. Katalogda, geliş yerleri belirtilmeyen bu eserler için Türkçe "emzik" kavramı kullanılırken, İngilizce metinde soru işaretli bir biçimde "feeding bottle" kavramının kullanıldığı göze çarpmaktadır. (Akat ve Fırat ve Kocabaş, 1984, s.70) Bundan sonra Türkiye Şişe ve Cam Fabrikaları A.Ş. Cam Eserler koleksiyonunda yer alan örnek gelir. Sağlam 
durumdaki bu örnek "Bizans camları" başlığı altında sunulmuş ve Antep’te bulunduğu kaydedilmiştir. Fakat kandilin neye dayanılarak Bizans devrine mâledildiği belirtilmemiştir. (Canav, 1985, s.96) Aynı kandil, muhtemelen Üzlifat Canav'ın tasnifine dayanılarak bir başka çalışmada daha Bizans devrine verilmiştir. (Bkz.; Aslan ve Yazar, 2015, s.17)

Bilinen diğer örneklerin tümü Samsat kazılarında ele geçmişlerdir. Yumurta biçimli Samsat kandillerinden ilk kez söz eden Gönül Öney, kazıda bunlardan bolca ele geçtiğini öne sürmesine rağmen sayı vermemiştir. (Öney, 1982. s.79) Buna karş1lık Nimet Özgüç, bu tipte iki kandile yer vermiştir. (Özgüç, 2009, s.20) Bunlardan birisini müzede göremedik. Diğeri sağlam durumda teşhirde yer almaktadır. (Karpuz, 2014, s.196) (Kat.no.17; Şekil 17; Resim 17) Müze deposunda yaptığımız çalışma sırasında Özgüç'ün yayınladıklarının dışında bu tipte üç örnek daha tespit ettik. (Kat.no.18, 19, 20) Bunlar kırıktır. Sadece alt kısımları mevcut olup şeffaf renksiz camdan yapılmışlardır. (Şekil 18,19,20; Resim 18,19,20) Serbest üfleme tekniğinde yapılmışlardır. Özgüç’ün kitabında yer alıp bizim de incelediğimiz sağlam kandilin yüksekliği $8.8 \mathrm{~cm}$, Özgüç’ün yayınladığ yüksekliği ise 7,8 cm iken; Hüseyin Kocabaş koleksiyonunda bulunan kandillerin yükseklikleri 8.5 ile $9 \mathrm{~cm}$ arasındadır. Buna karşılık Üzlifat Canav'ın tanıttı̆̆ 1 eserin yüksekliği 10,1 cm'dir. Boyutlarında her ne kadar küçük farklılıklar bulunsa da bu kandiller Samsat'tan başka yerde bulunmamıştır. Bu durum, Hüseyin Kocabaş koleksiyonunda ve Şişe Cam koleksiyonunda yer alan kandillerin de Samsat kökenli olmaları gerektiğini düşündürmektedir. Diğer taraftan, bunlardan en az ikisinin höyükte "kule" denilen ve Selçuklu devri özelliği yansıtan yapıda bulunmuş olmaları, söz konusu yumurta biçimli kandillerin 12-13. yüzyıllara verilebileceğini göstermektedir.

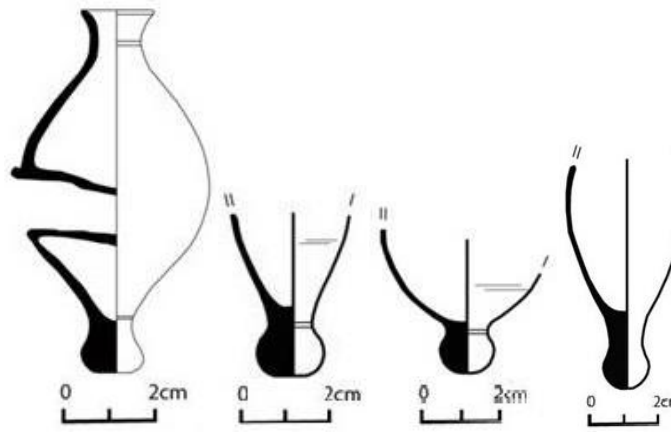

Şekil 17,18,19,20. Yumurta biçimliler

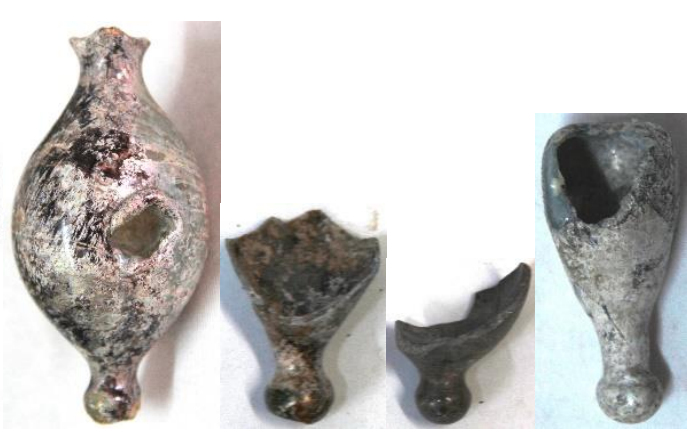

Resim 17,18,19,20. Yumurta biçimliler

\section{Sonuç:}

Samsat Höyüğünün çok az bir kısmı kazılabilmiş olmasına rağmen, cam sanatı açısından son derece zengin buluntularla karşılaşırız. Bu camlar arasında aydınlatma araçlarından kandiller çeşitliliği ile önem taşırlar. Yayınlanmış kazı raporları, kitap ve müze kayıtlarında cam buluntulara ilişkin stratigrafik ayrıntılar yeterli olmadığından; kandillerin aidiyetlerinin belirlenmesi ve tarihlendirilmelerinde üslûp ve teknik özellikler esas alınmıştır.

$\mathrm{Bu}$ doğrultuda ele aldığımız Samsat cam kandilleri için sonuç bağlamında şunlar ifade edilebilir:

$\mathrm{Bu}$ kandiller serbest üfleme tekniği ile meydana getirilmişlerdir. Vazo tipli kandil ve kâse gövdeli kandil tipinde görülen kulplar ise kap biçimlendirildikten sonra eklenmişlerdir. İncelediğimizparçalardan ondördü (Kat.no.2,7,8,9,10,11,12,13,14,16,17,18,19,20) şeffaf renksiz camdan yapılmıştır. Birer örnek kobalt mavisi (Kat.no.3) ve nefti yeşil Kat.no. 4 renktedir. Dört parçada ise (Kat.no.1,5,6,15) şeffaf yeşilimtrak renk görülmektedir.

\section{Turkish Studies - Social Sciences}

Volume 14 Issue 3,2019 
Bardak biçimli kandiller arasındaki gövdesi çan biçimli olanlar, yayınlanan eserlerde genellikle 2.-4. yüzyıla verilmektedirler. Fakat bu kandil formunun örneklerini 7. yüzyıla kadar görmek mümkündür. Bu nedenle, Samsat'taki bardak biçimli kandil, en geniş zaman aralığıyla 2-7. yüzyıllar arasına tarihlendirebilir.

Samsat buluntuları arasında bir örnekle temsil edilen kulplu kase gövdeli kandil tipi hem Bizans döneminde hem de erken İslam döneminde uygulanmıştır. Bu tipin Anadolu'daki Bizans merkezlerinde karşılaşılan örnekleri 11-12. yüzyıllara tarihlenmişlerdir. Buna karşılık Suriye- Filistin, Ürdün bölgelerinde kulplu kâse gövdeli kandiller 5. yüzyıldan itibaren tespit edilmekte ve Bizans, Emevi ve Abbasi dönemleriyle ilişkilendirilmektedir. Samsat'ın coğrafi bakımdan bu bölgelerle komşuluğu ve tarihini dikkate alarak bu örnek için 5-8. yüzyıllar arası önerilmiştir.

Çubuklu kandiller türünün alt grubu olarak içi boş, boğumlu çubuklu, ucu bilye şeklinde olan tipleriyle karşılaşılmıştır. İçi boş çubuklu kandiller erken Bizans dönemine tarihlenirler. Bu gruptan tek örneğimizi bölgedeki Bizans egemenlik süresini dikkate alarak Erken Bizans dönemine (5 -7.yy.) tarihledik. Boğumlu çubuklu gruba giren parçalar özellikle Filistin bölgesindeki benzer örneklerinden hareketle 4- 8. yüzyıla tarihlendirilebilirler. Ucu bilye şeklinde olan kandiller ise 5. yüzyıldan 14. yüzyıla kadar çok geniş zaman aralığında üretilmişlerdir. Dönemsel olarak hem Bizans, hem de İslam coğrafyasında bu tip kandillerin üretilip kullanıldıkları anlaşılmaktadır. Bunlar, şehirde hem Bizans hem de İslami dönem egemenliği dikkate alınarak en geniş zaman aralığıyla 5-12. yüzyıllara tarihlenebilirler.

Vazo biçimli kandiller İslam cam sanatında yaygın olarak kullanılan kandil tipidir. İslam camcillğında bu tipin erken örnekleri 8-10 yüzyıllar arasına tarihlenmektedir. Nadiren 7. yüzyıldan örnekler bilinmektedir. Memlûk döneminde bu kandiller çok çeşitli boylarda üretilmişler ve yüzeyleri mineleme tekniği ile bezenmişlerdir. Bizim kandilimiz bu örnekler gibi süslemeli ve gösterişli ve büyük değildir. Sade işçiliği ile Kubad Abad ve Beçin kazılarında ele geçen örneklere benzemektedir. Fakat hem boyutunun küçüklügü, hem de bezemesiz oluşu bakımlarından, Nişapur, Berlin Staatliche Museum ve El-Sabah koleksiyonunda yer alan bezemesiz ve küçük boyutlu kandilleri daha çok andırmaktadır. Yakın Doğu, Suriye veya İran kökenli olduğu kaydedilen söz konusu kandiller gibi bizim örneğimizin de 10-12. yüzyıllardan kalma bir İslam eseri olduğu görüşündeyiz. Bu kronoloji, söz konusu Samsat kandilinin Selçuklu devrinden kalmış olabileceğini de akla getirmektedir.

Samsat'ta omuzlu kandiller grubundan bir örnek karşımıza çıkar. Nadir görülen bu tipin ilk örnekleri Kubad Abad kazılarında bulunmuş ve 13. yüzyıla tarihlenmişlerdi. Samsat'ın omuzlu kandil parçası da, bu tipin nadir örneklerinden birisi olarak 13. yüzyıla verilmelidir.

Yumurta biçimli kandil tipi için ise şimdilik sadece Samsat örneklerini biliyoruz. Bu kandil tipi ile ne Bizans sahasında ne de başka İslam merkezlerinde karşılaşılmıştır. Fakat yeni yapılacak araştırma ve kazılarda bu tespiti değiştirebilecek sonuçların çıkması olasıdır. Mevcut buluntular -en azından şimdilik- yumurta biçimli kandillerin üretim yerinin Samsat olduğunu göstermektedir. Diğer yandan bunlardan ikisinin, höyükte Selçuklu ve sonrasını barındıran I. kültür katında, "kule" denilen ve Selçuklu özelliği taşıyan binada ele geçmiş olmaları; söz konusu kandillerin 12-13. yüzyıllardan kalmış olduklarını göstermektedir .

Samsat kazılarında fırın ele geçmediğinden kandillerin Samsat'ta üretilip üretilmediklerini belirlemek zordur. Fakat ele geçen cam külçeleri; burada Bizans devrinden itibaren üretim yapıldığına işaret etmektedir. Bu üretimin İslamî dönemde de devam ettiği söylenebilir. Samsat kazılarında bulunan cam kandillerden; bardak tipli kandil (kat.no.1) ile içi boş çubuklu örneğin (kat.no.3) Bizans dönemine aidiyeti konusunda kuşku taşımıyoruz. Fakat kâse tipli kandiller ile boğumlu çubuklular ve ucu bilyeli çubuklu kandillerin hem Bizans, hem de İslam döneminde yapıldıkları kabul edilmektedir. Bu nedenle bizim incelediğimiz kâse tipli kandil (Kat.no.2), boğumlu çubuklular (Kat.4,5,6) ve ucu bilyeli çubuklu kandil parçalarının (Kat.no.7,8,9,10,11,12,13,14) da her iki dönemde de üretilmiş 
olmaları mümkündür. Buna karşılık, vazo tipli (Kat.no.15) ve omuzlu (Kat.16) kandil parçası İslamî döneme aittirler. Fakat sadece Samsat kazılarından bilinen yumurta tipliler (Kat.no.17,18,19,20) için henüz dönem ve tarih vermek mümkün değildir. Bir grup kulpun kandillere aidiyetleri konusunda şüphe yoksa da, bunların ne tip örneklere ait olduklarını kestirmek imkansızdır. Diğer taraftan, Samsat kandillerindeki renk skalasının şeffaf renksiz, kobalt mavisi, şeffaf yeşilimtrak ve neftî yeşille sınırlı olduğu; dekoratif bakımdan ise çok sade eşyalar oldukları dikkatten kaçmamaktadır.

\section{Katalog:}

Kat.no.1:Bardak tipli kandilin kısmen kaide ve gövde kısmı ele geçmiştir. Gövdesi çan biçimlidir. Mevcut yüksekliği $6.5 \mathrm{~cm}$ 'dir. Şeffaf yeşilimtrak renktedir.

Kat.no.2:Kulplukâse gövdeli tipteki kandil şeffaf renksiz camdan yapılmıştır. Gövde kısmı kırıktır. Ağız çap 10.4 cm'dir.

Kat.no.3: İçi boş çubuklu kandil tipindedir. Mevcut yükseklik $4.6 \mathrm{~cm}$, çubuk kalınlığı 1.5 cm'dir. Kobalt mavisi rengindedir.

Kat.no.4: Boğumlu çubuklu kandil tipindedir. Mevcut yükseklik $3.5 \mathrm{~cm}$, çubuk kalınlığg $1.5 \mathrm{~cm}$ 'dir. Nefti yeşil rengindedir.

Kat.no.5: Boğumlu çubuklu kandil tipindedir. Mevcut yükseklik $6.8 \mathrm{~cm}$, çubuk kalınlığı $1.5 \mathrm{~cm}$ 'dir. Şeffaf yeşilimtrak renktedir.

Kat.no.6: Boğumlu çubuklu kandil tipindedir. Mevcut yükseklik $5.5 \mathrm{~cm}$, çubuk kalınlığı 1.6 cm'dir. Şeffaf yeşilimtrak renktedir.

Kat.no.7:Ucu bilye biçiminde düz çubuklu kandildir. Mevcut yükseklik 6.3 cm'dir. Şeffaf renksiz camdan yapılmıştır.

Kat.no.8: Ucu bilye biçiminde düz çubuklu kandil tipindedir. Mevcut yükseklik 4.4 cm, en 1.3 cm'dir. Şeffaf renksiz camdan yapılmıştır.

Kat.no.9:Ucu bilye biçiminde düz çubuklu kandil tipindedir. Mevcut yüksekliği $10.8 \mathrm{~cm}$, gövde genişliği $6 \mathrm{~cm}$, çubuk yüksekliği $4.8 \mathrm{~cm}$ 'dir. Şeffaf renksiz camdan yapılmıştır.

Kat.no.10: Ucu bilye biçiminde düz çubuklu kandil tipindedir. Mevcut yüksekliği $8.4 \mathrm{~cm}$, gövde genişliği $8 \mathrm{~cm}$ çubuk kalınlığı $1.3 \mathrm{~cm}$ 'dir. Şeffaf renksiz camdan yapılmıştır.

Kat.no.11: Ucu bilye biçiminde düz çubuklu kandil tipindedir. Mevcut yüksekliği $6.3 \mathrm{~cm}$, çubuk kalınlığı 1.5 cm'dir. Şeffaf renksiz camdan yapılmıştır.

Kat.no.12: Ucu bilye biçiminde düz çubuklu kandil tipindedir. Mevcut yüksekliği $6.8 \mathrm{~cm}$, çubuk kalınlığ 1.5 cm'dir. Şeffaf renksiz camdan yapılmıştır.

Kat.no.13: Ucu bilye biçiminde düz çubuklu kandil tipindedir. Mevcut yüksekliği $5.5 \mathrm{~cm}$, çubuk kalınlığ 1.6 cm'dir. Şeffaf renksiz camdan yapılmıştır.

Kat.no.14: Ucu bilye biçiminde düz çubuklu kandil tipindedir. Mevcut yüksekliği 5.7 cm'dir. Şeffaf renksiz camdan yapılmıştır.

Kat.no.15: Vazo biçimli kandil tipindedir. Mevcut yüksekliği $9 \mathrm{~cm}$, boyun $3.5 \mathrm{~cm}$, gövde çapı 7.2 cm'dir. Şeffaf yeşilimtrak renktedir.

Kat.no.16: Omuzlu kandil tipindedir. Kaide çapı $4 \mathrm{~cm}$, mevcut gövde yüksekliği $8,5 \mathrm{~cm}$ 'dir. Şeffaf renksiz camdan yapılmıştır. 
Kat.no.17: Yumurta biçimli kandil tipindedir. Yüksekliği $8.8 \mathrm{~cm}$ 'dir. Kaide çap1 $1 \mathrm{~cm}$ 'den başlayarak yukarı doğru 1.5 cm'e kadar çıkmaktadır. Gövde çapı 4.5 cm'dir. Şeffaf renksiz camdan yapılmıştır.

Kat.no.18: Yumurta biçimli kandil tipindedir. Mevcut yüksekliği $5 \mathrm{~cm}$ 'dir. Gövde genişliği $3.5 \mathrm{~cm}$ 'dir. Kaide çap $1.5 \mathrm{~cm}$ 'dir.Şeffaf renksiz camdan yapılmıştır.

Kat.no.19: Yumurta biçimli kandil tipindedir. Mevcut yüksekliği 4 cm'dir. Gövde genişliği $3.5 \mathrm{~cm}$, kaide çapı $1.5 \mathrm{~cm}$ 'dir. Şeffaf renksiz camdan yapılmıştır.

Kat.no.20: Yumurta biçimli kandil tipindedir. Mevcut yüksekliği $6.3 \mathrm{~cm}$ 'dir. Gövde genişliği $3 \mathrm{~cm}$, kaide çapı 1.1dir.Şeffaf renksiz camdan yapılmıştır.

\section{KAYNAKÇA}

Acara, M.- Olcay, B.Y. (1998). Bizans döneminde Aydınlatma Düzeni ve Demre Aziz Nikolaos Kilisesi'nde Kullanılan Aydınlatma Gereçleri, Adalya, No.II/1997, s.249-266.

Akat, Y.- Fırat,N.- Kocabaş, H. (1984). Hüseyin Kocabaş Cam Eserler Koleksiyonu, Nezih Başgelen (Haz), İstanbul.

Arseven C.E. (1965). Sanat Ansiklopedisi, 2, İstanbul.

Aslan, T.- Yazar, T. (2015). Geleneksel El Sanatları Bağlamında Kültür Ürünleri Olarak Türk Cam Sanatı: Surname-i Hümayun Analizi. Turkish Studies - International Periodical for The Language, Literature and History of Turkish or Turkic, Volume 10/5 Winter 2015, p.13-26.

Bulut, L.(2000). Samsat Ortaçă̆ Seramikleri (Lüster ve Straltılar), İzmir: Ege Üniversitesi Yayınları.

Burdajewicz, M. (2006). Glass Finds From The North-West Church Complex, Hippos Sussita: Seventy Season of Excavations (July 2006) içinde (p.127-143).Haifa: Zimman Institute of Archaeology University of Haifa.

Burdajewicz, M.(2017). Glass Finds From Beit Ras/ Capitolias (Jordan), Polish Archaeology in TheMediterranean (PAM), 26/1, 661-686.

Canav, Ü. (1985).Türkiye Şişe ve Cam Fabrikaları A.Ş., Cam Eserler Koleksiyonu, İstanbul.

Carboni,S. (2001). Glass From Islamic Lands, The Al Sabah Collection Kuwait National Museum, London.

Clairmont, C.W.(1963). The GlassVessels, The Excavations At Dura Europos Final Report IV, PartV, New Hawen.

Crowfoot G. M. - Harden D.B. (1931). Early Byzantine and Later Glass Lamps, The Journal ofEgyptian Archaeology ,17, 196-208.

Çakmaklı, Ö. D. (2012). Karia Bölgesi Roma Dönemi Cam Kap tipolojisi, (Yayınlanmamışdoktora tezi ) Ankara Üniversitesi /Sosyal Bilimler Enstitüsü, Ankara.

Çakmakçı, Z. (2017). Bizans Dönemi Mekan Aydınlatmasında "İslami Tipte" Cam Kandiller, Anadolu Üniversitesi Sosyal Bilimler Dergisi,Anadolu Üniversitesi Yayınları,3670, Eskişehir, s.163180.

Çömezoğlu, Ö. (2007). Akdeniz Çevresi Ortaçă̆ Camcılı̆̆̆ Işı̆̆ında Demre Azis Nikolaos KilisesiCam Buluntuları. (Yayınlanmamış doktora tezi). İstanbul Üniversitesi/Sosyal Bilimler Enstitüsü İstanbul. 
Davidson, G.R. (1952). Corinth XII: The Minor Objects, Princeton: The American School of Classical Studies at Athens.

Devellioğlu, F. (2002). Osmanlıca-Türkçe Ansiklopedik Lügat (19. bask1).Ankara.

Demirkent, I.(1997). Sümeysât. İslam Ansiklopedisi, 11, s.232-236.

Gill, M.A.V. (2002). Amorium Reports, Finds I: The Glass (1987-1997), BAR International Series 1070, England.

Goell, T. (1974). Samosata Archaeological Excavations, Turkey,1967, National Geographic Society Research Reports, 1967 Projects içinde (s.83-109). Washington D.C.

Gorin-Rosen, Y. - Winter, T. (2010). Selected insights into Byzantine glass in the Holy Land, Jörg Drauscke - Daniel Keller (Ed.),Glass in Byzantium - Production, Usage, Analyses içinde (s.165-181). Mainz: Verlag des Römisch-Germanischen Zentralmuseums.

Gök, S. (2004). 2000 Yı1ı Beçin Kazısında Bulunan Cam Kandil Hakkında, Sanat Tarihi Dergisi (Aydoğan Demir'e Armağan), XIII/1, İzmir, s. 33-41.

Hadad, S. (1998). Glass Lamps from the Byzantine Through Mamluk Periods at Bet Shean. Journal of Glass Studies, 40, 63-76.

İbn Bibi (1996). El Evamirü'l-Ala'iye fi'l-Umuri'l-Ala’iye (Selçuk Name), Mürsel Öztürk (Haz.), Ankara: T.C. Kültür Bakanlığı Yayını.

İzmirligil, Ü.(1987). Samosata (Samsat) Su Yolu Araştırmas1 1978-1979 / The Samosata (Samsat) Aqueduct Investigations, 1978-1979. Aşağl Fırat projesi 1978-1979 Çalışmaları içinde (s.281-289), Ankara: ODTÜ Aşağı Fırat Projesi Yayınları.

Kalfazade, S.- Ertuğrul,Ö. (1989). Kandil ve Kandilin Motif Olarak Anadolu Türk Sanatındaki Kullanımı Üzerine, Sanat Tarihi Araştırmaları Dergisi, 5, İstanbul, s.23-34.

Karpuz, G.G.(2014). Adıyaman, Elazı ğ, Hatay, Mardin, Şanlıurfa Müzelerinde Bulunan İslami Dönem Cam Eserler, (Yayınlanmamış doktora tezi). Atatürk Üniversitesi/ Sosyal Bilimler Enstitüsü, Erzurum.

Köroğlu, G. (2009). Glass From Yumuktepe (Cilicia). Ergun Laflı (Ed.), Late Antique / Early Byzantine Glass in The Eastern Mediterranean içinde (s.235-243). İzmir: Hürriyet Matbaası.

Köroğlu,G. (1999). Yumuktepe Höyüğü 1997 Yılı Ortaçağ Kazı Çalışmaları ve İslam Dönemine Ait Bir Cam Kandil, Olba (I.Uluslararası Kilikia Arkeolojisi Sempozyumu Bildirileri) II/1, Mersin,s.241-252.

Kröger, J.(1995). Nishapur: Glass of the Early Islamic Period. New York: The Metropilitan Museum of Art.

Kucharczyk, R. (2008). Glass from Area F on Kom El Dikka (Alexandria): Excavations 2008, Polish Archaeology in the Mediterranean, 20, 56-69.

Lamm,C.J.(1929). Mittelalterlische Gläser und Steinschnittarbeiten aus dem Nahen Osten, II, Berlin: Verlagdietrichreimer / Ernst Vohsen.

Lamm,C.J.(1930). Mittelalterlische Gläser und Steinschnittarbeiten aus dem Nahen Osten, I, Berlin: Verlagdietrichreimer / Ernst Vohsen.

Olcay, B.Y. (1997). Antalya'nın Demre (Kale) İlçesindeki Azis Nikolaos Kilisesi Kazısı 19891995Yılları Cam Buluntuları. (Yayınlanmamış doktora tezi). Hacettepe Üniversitesi /Sosyal Bilimler Enstitüsü, Ankara. 
Olcay, B.Y. (1998). Bizans Döneminin Cam Sanatı Tarihi İçindeki Yeri.Anadolu Sanat, 8, 145-166.

Olcay, B.Y.(2001).Lighting Methods In the Byzantine Period and Findings of Glass Lamps inAnatolia,Journal of Glass Studies,43, 77-87.

Olcay Uçkan, B.Y. - Öztaşkın, M.(2017). Olympos Kazılarında Bulunan Aydınlatma Gereçleri. Seleucia, VII, s.11-28.

Olcay Uçkan, Y.- Bulgurlu, V. - Çömezoğlu, Ö. (2007). Lüks Üretimde ve Günlük Kullanımda Cam Sanatı. Ayla Ödekan (Ed.), Kalanlar: 12. ve 13. Yüzylllarda Türkiye'de Bizans içinde (s.4245). İstanbul: Vehbi Koç Vakfi.

Oral Çakmakçı, Z. (2008).Örnekler Işı̆ğında Bizans Asia'sında Cam Sanatı, (Yayınlanmamış doktora tezi), Ege Üniversitesi /Sosyal Bilimler Enstitüsü, İzmir.

Öney, G. (1982). 1978-79 ve 1981 Y1lı Samsat Kazılarında Bulunan İslam Devri Buluntularıyla İlgili İlk Haber, Arkeoloji Sanat Tarihi Dergisi, 1, İzmir, s.71-80.

Özgüç, N. (2009). Samsat, Sümeysat,Samosata, Kumaha,Hahha, Hahhum, Bir Başkent ve KaleninUzun Yaşamının 6000 Yıllık Döneminden Kesitler,Ankara.

Özgümüş, Ü. (1993-1994). Anadolu'da Bizans Dönemi Camcılı̆̆ı. Sanat Tarihi Araştırmaları Dergisi, $12,12-43$.

Philippe, J. (1970). Le Monde Byzantin Dans L'Histoire de la Verrerie, Bologna.

Redford, S. (1994). Ayyubid Glass from Samsat, Turkey, Journal of Glass Studies,36, 81-91.

Riis, P.J. - Poulsen, V. (1957). Hama: Fouilles et Recherches 1931-1938. Copenhague: Fondation Carlsberg.

Saldern A.V. (1980)Ancient and Byzantine Glass From Sardis, (Sardis Monographs 6),Cambridge.

Serdaroğlu, Ü. (1977). Aşağı Fırat Havzasında Araştırmalar 1975/ 1975 Surveys in The Lower Euphrates Basin, Ankara: ODTÜ Aşağı Furat projesi Yayınları.

Temur, A. (2018). Sinop Müzesi Erken Bizans Dönemi Cam Kandilleri, Tarih Okulu Dergisi(TOD), XXXIII, İzmir, s.227-267.

Turan, O. (1971). Selçuklular Zamanında Türkiye Tarihi, İstanbul: Nakışlar Yayınevi.

Uçkan Olcay, B.Y.(2017). Olympos Kazısı Cam Buluntuları, Yelda Olcay Uçkan (Ed.), Olympos I,2000-2014 Araştırma Sonuçları içinde (s.195-208), İstanbul:Akmed.

Uçkan Olcay, B.Y.-Uzbek Çömezoğlu, Ö. (2018).Cam Buluntular,Sema Doğan-Ebru Fatma Fındık (Ed.), Aziz Nikolaos Kilisesi Kazıları 1989-2009 içinde (s.513-551). İstanbul: Homer.

Uysal, Z. (2007). Kubad Abad Kazılarında Bulunan Cam Kandiller,Yeni İpekyolu Dergisi,X, Özel Sayı (Rüçhan Arık-M.Oluş Arık'a Armağan), Konya, s.725-734.

Uysal, Z. (2013). Kubad-Abad Sarayında Selçuklu Cam Sanatı, Ankara.

Wiet, G.(1929). Catalogue General du Musée Arabe du Caire: Lampes et Bouteilles en Verre Emaillée. Paris.

Wiet,G.(1929). Cataloque General du Musee Arabe du Caire; Lampes et Bouteilles enVerre Emaille, Paris.

Wilson Pinder, R.H. - Scanlon G.T. (1973).Glass Finds From Fustat: 1964-71, Journal of Glass Studies, 15,12-30. 
Yonar, L.(2003). Türk İslam Sanatında Cam Kandiller (9-14. Yüzyıllar Arası). (Yayınlanmamış yüksek lisans tezi). Mimar Sinan Üniversitesi / Sosyal Bilimler Enstitüsü, İstanbul. 